\title{
Nanoparticles as a control for cyanobacterial bloom
}

\author{
Vật liệu nano đóng vai trò kiểm soát sụ bùng nổ của vi khuẩn lam \\ Research article
}

Tran, Thi Thu Huong 1,2; Nguyen, Trung Kien ${ }^{2}$, Nguyen, Thi Thuy Thi ${ }^{2}$; Ha, Phuong Thu ${ }^{3}$; Le, Thi Phuong Quynh ${ }^{4}$; Do, Van Binh ${ }^{1}$; Dinh, Thi Hai Van ${ }^{5}$; Trinh, Quang Huy ${ }^{5}$ Duong, Thi Thuy ${ }^{*}$

${ }^{I}$ Faculty of Environment, Hanoi University of Mining and Geology (HUMG), Ha Noi, Viet Nam; ${ }^{2}$ Institute of Environmental Technology, VAST, Ha Noi, Viet Nam; ${ }^{3}$ Institute of Materials Science, VAST, Ha Noi, Viet Nam; ${ }^{4}$ Institute of Natural Products Chemistry, Ha Noi, Viet Nam, ${ }^{5}$ Faculty of Environmental, Vietnam National University of Agriculture, Chau Quy, Gia Lam, Hanoi

\begin{abstract}
This study aims to investigate the toxicity of copper material synthesized by chemical reduction method and effects of environmental variables on growth of phytoplankton community (dominated by Microcystis genus) in the Tien eutrophic lake, Hanoi, Vietnam. The variables analyzed include: physical (pH and Turbidity), chemical (content of NH4+, PO43- and copper metal), biological (content of Chlorophyll-a, cell density). The characteristic of nanomaterial was confirmed by using UVvisible spectrophotometer, XRD, SEM and TEM methods. The CuNPs showed they spherical form and uniform size about 20-40 $\mathrm{nm}$. The experimental results showed that the treated with CuNPs inhibition on growth against phytoplankton after 8 days. The cell density of phytoplankton community and Microcystis genus in samples exposure with CuNPs declined after 8 days from 647.037 and 467.037 down to 381.111 and 202.592 , respectively.
\end{abstract}

\begin{abstract}
Mục đích của nghiên cúu này là khảo sát độc tính của vật liệu nano đồng được tổng hợp bằng phuơng pháp khư hóa hoc và ảnh hương của các yếu tố môi trương đến sinh trưởng và phát triền của quần xã thưc vật nổi (chủ yếu là chi Microcystis) trong nước hồ Tiền phú duõ̃ng, tại Hà Nội, Việt Nam. Các thông số phân tích bao gồm: thủy lý ( $p H$ và độ đục), hóa học (hàm luợng amoni, photphat và hàm luợng đồng kim loại), sinh học (hàm luợng chất diệp lục, mật độ tế bào). Đặc trung của vật liệu được xác định bằng các phuơng pháp quang phổ UV-VIS, XRD, SEM và TEM. Vật liệu nano đồng có dạng hình cầu, kích thước đồng nhất tù̀ 20 đến $40 \mathrm{~nm}$. Kết quả thủ nghiệm sau 8 ngày cho thấy các mẫu có bổ sung vật liệu nano đồng ức chế sinh truởng quần xã thực vật nổi ở nồng độ $1 \mathrm{mg} / \mathrm{l}$. Mật độ quần xã thực vật nổi và chi Microcystis trong mẫu xủ lý với CuNPs đã giảm tương úng sau 8 ngày tù̀ 647.037 và 467.037 xuống còn 381.111 và 202.592.
\end{abstract}

Keywords: Cyanobacteria, Microcystis aeruginosa, inhibition, nanoparticles

\section{Introduction}

Eutrophication occurs due to the increases of phosphate and nitrate concentrations in aqueous, where the bloom growth of the cyanobacteria species could be observed. Cyanobacteria as a primary producer could play major function in photosynthesis, they create food chain in water environment and in material recycle (Wang et al, 2011). Microcystis genus belongs to cyanobacteria that is widely distributed from nutrient-poor freshwater to brackish water and sea water. However, cyanobacteria can also pose many serious environmental and health risks (Blahoslav et al,
2012). They create a serious threat to quality of water resources, alter aquatic ecosystems and cause water pollution problem like "water blooming" over the world (Blahoslav et al, 2012). Therefore, prevention and decrease the powerful development of cyanobacteria are important environmental issues.

Nanotechnology is the technology relating to the synthesis and application of materials with nanometre sizes (nm) (B. Mahltig et al, 2013). At the nanoscale, materials will have special features than traditional materials because their specific size is smaller than $100 \mathrm{~nm}$, larger surface to volume ratio, crystalline structure, high reactivity potential, 
creating the effect of resonance Plasmon surface (Jayatissa et al, 2006; Park et al, 2006). Because of many advantage features and dimensions equivalent to the biomolecular nanotechnology is being invested in research in many fields such as biomedical, pharmaceutical, biotechnology and especially in environmental pollutant treatment.

With the advantage characteristics, copper nanomaterial was applied in various fields such as semiconductor materials, polymers, films, biomonitoring, wastewater treatment and antimicrobial agent in many biomedical applications (Fred Rispoli et al, 2010; Ingle et al, 2014). However, the release of nanoparticles into ecosystem can pose many risks for environment, aquatic organisms and human health, in which it has been observed to be increasing in various waters around the world, including altered community composition (Das et al, 2012), the metabolism of ecosystem (Colman et al, 2014) and nutrient cycling (Choi et al, 2009). Recently, some studies showed the toxicity of CuNPs to yeast (Kasemets et al, 2009), microalgae (Aruoja et al, 2009), bacteria (Heinlaan et al, 2008) but effect of CuNPs on phytoplankton community at pilot scale is limited.

This study aims to investigate the potential effects of nanoparticles on phytoplankton assemblage under natural lake environmental conditions. The tested samples were taken from the eutrophic water in Tien Lake. Tien Lake is a small lake located in Hanoi city, Viet Nam. It is seriously polluted because of many pollution sources from food, wastewater and surface water. Microcystis genus is accounting for $80 \%$ of phytoplankton communities in Tien Lake. In our studies, the tested variables were selected based on the most likely natural conditions that could be found in an aquatic environment. The influence of these variables on the toxicity of CuNPs was investigated by using an aquarium design of experiment. The concentration of nanoparticle is determined based on the results of laboratory tests previously. A significant inhibition on growth and development of phytoplankton community in aquarium tanks exposure with CuNPs was observed.

\section{Materials and methods}

\subsection{Experiment setup}

The experiment was carried out with a phyto-plankton assemblage collected from a eutrophic lake (Tien Lake, Bach Khoa Ward, Hanoi) in which cyanobacterial Microcystis genus was dominant. The experiment was performed in aquarium tanks containing approximately 10 liters of water collected from Tien Lake. Copper nanoparticles (CuNPs) were added in aquariums with the concentration of $1 \mathrm{ppm}$. Aquariums which contain only lake water (untreated with CuNPs) were used as control sample. The experiment was performed in triplicate, in 8 days under room conditions without aeration process. During the experiment, physical variables ( $\mathrm{pH}$, Turbidity), chemical variables $\left(\mathrm{NH}_{4}{ }^{+}, \mathrm{PO}_{4}{ }^{3-}\right.$ and copper concentrations) and phytoplankton biomass (Chlorophyll a), density of cell were monitored at Day 0, $1,2,3,4,8$. The $200 \mathrm{ml}$ of the surface water samples were collected from the aquarium tanks in these days and used to determine the chemical and biological variables.

\subsection{Chemical synthesis of copper nanoparti- cles}

The copper nanoparticles were synthesized by a chemical reduction method at room temperature (overall procedure showed in figure 1). Copper (II) sulfate salt, $\mathrm{CuSO}_{4}$ $(>99 \%$ ) acting as the precursor for the formation of $\mathrm{Cu}$ nanoparticles was purchased from the Merck Chemical Reagent Co. Sodium borohydride, $\mathrm{NaBH}_{4}$, of $98 \%$ purity used as the main reducing agent was purchased from the Scharlab (Sentmenat, Barcelona, Spain). In this typical procedure for preparing $0.4 \mathrm{~g}$ of copper metal nanoparticles, $1 \mathrm{~g}$ of $\mathrm{CuSO}_{4}$ was added to $200 \mathrm{ml}$ deionized water in a flask and vigorously stirred by a IKA RW20 digital stirrer at $1500 \mathrm{rpm}$ for $15 \mathrm{~min}$ to dissolve the salt completely. Without disrupting stirring, $0.48 \mathrm{~g}$ of $\mathrm{NaBH}_{4}$ was poured into the flask and the stirring was continued for $10 \mathrm{~min}$ extra. The precipitate was separated from the supernatant by a Universal 32R D- 78523 centrifuge (Germany) (rotation speed of $9000 \mathrm{rpm}$ ). As long as the zerovalent copper nanoparticle was able to form a thin oxide layer film on its surface, there was no need to use a capping agent. To remove accompanied ions, the precipitate was washed thoroughly with $96^{\circ}$ ethanol (not less than five times) using centrifuge for precipitates' separation. Then the purified precipitate was vacuum-dried overnight at $70^{\circ} \mathrm{C}$ to obtain the powdery copper metal nanoparticles. The obtained nanocrystalized metals in the form of superdispersive powders were stored in hermetic flasks filled with argon gas.

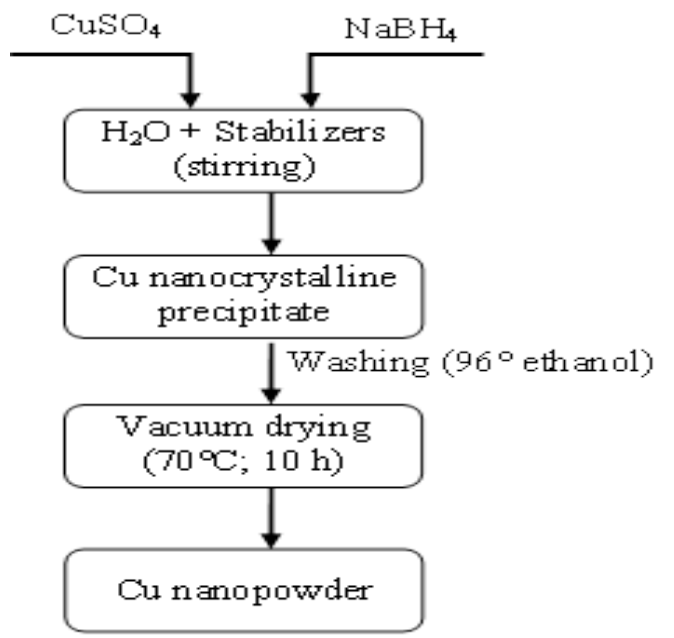

Figure 1. Overall procedure for preparing nanopweder by chemical reduction method

Morphology and size of the nanoparticles were examined using a scanning electron microscope (SEM) (FESEM, S4800 - Hitachi, Japan), a transmission electron microscope (TEM) (JEOL-JEM1010, Japan) and the XRD measure using a BRUCKER D8-Advance 5005 diffractometer with $\mathrm{Cu} \mathrm{K} \alpha$ radiation.

\subsection{Effect of nanoparticles on natural Phytoplankton Assemblage}

\subsubsection{Cell counting by optical microscopy}

Number of cells was counted directly by using a Neurbeur counting chamber under light microscope after dispersing the Microcystis cells by sonication. 
Chlorophyll-a concentration was determined by the Lorenzen (1967) method, as following: $10 \mathrm{~mL}$ of sample water was filtered through a Whatman GF/C glass paper filter (47 mm diameter) and followed by extraction in $10 \mathrm{ml}$ of $90 \%$ acetone. The spectrophotometrically absorbance of the sample was measured at $750 \mathrm{~nm}$ and $650 \mathrm{~nm}$ by an UVVIS V-630 (JASCO, Japan), before and after acidification, and the concentration of Chlorophyll a was determined according to the equations of Lorenzen (1967).

\subsubsection{Ammonium $\left(\mathrm{NH}_{4}{ }^{+}\right)$and Phosphate $\left(\mathrm{PO}_{4}{ }^{3-}\right)$ meas- urement}

$\mathrm{NH}_{4}{ }^{+}$and $\mathrm{PO}_{4}{ }^{3-}$ were measured by Nessler and Ascorbic methods, respectively.

\subsubsection{The content of copper metal}

AAS (Atomic Absorption Spectrophotometric) (Shimadzu - Japan) method used to measure the content of copper metal on the first day and last day of experimental period.

\subsubsection{Statistical analysis}

All experiments were done in triplicate and the data were calculated as mean \pm SD (standard deviation) and drawn by the software excel 2010 and SPSS version 23.0. Statistical significance was accepted at a level of $p<0,05$.

\section{Results and discussion}

\subsection{Characteristics of copper nanoparticles}

Figure 2 shows the SEM and TEM images of nanocrystalline copper prepared by chemical reduction method. It can be seen that the size of the synthesized copper is in the range of nanometer. The particles have spherical form and uniform size about $20-40 \mathrm{~nm}$. XRD patterns of the copper nanoparticles prepared for this work are displayed in figure 3 with $2 \theta$ values between $25^{\circ}$ and $80^{\circ}$. The XRD pattern in figure 3 shows three characteristic peaks at $43.4^{\circ} ; 50.6^{\circ}$ and $74.2^{\circ}$ for the respectively marked indices of (111), (200) and (220). These characteristic peaks confirm the formation of a face-centered cubic (FCC) copper phase. A small peak is also observed at around $36.5^{\circ}$ indicates that a small amount of copper was oxidized and converted into copper oxide. However, thanks to this thin firm oxide layer on its surface, there was no need to use a capping agent for synthetic process of copper nanoparticles and therefore, the crystalline centers appeared with a higher speed, resulted in the formation of small particles (Quoc et al, 2014). The average primary particle size of the copper nanoparticles was calculated from the XRD data according to Scherrer's equation:

$$
D=\frac{0.9 \times \lambda}{\beta_{1 / 2} \times \cos \theta},
$$

Where $\lambda$ is the wavelength $(\AA)$ of characteristic X-ray, $\beta 1 / 2$ is half-value with of peak obtained by XRD and $\theta$ is $43.4^{\circ} / 2$ (Klug et al, 1997). In this case, the copper nanoparticles crystallites size was estimated to be at $23.16 \mathrm{~nm}$.
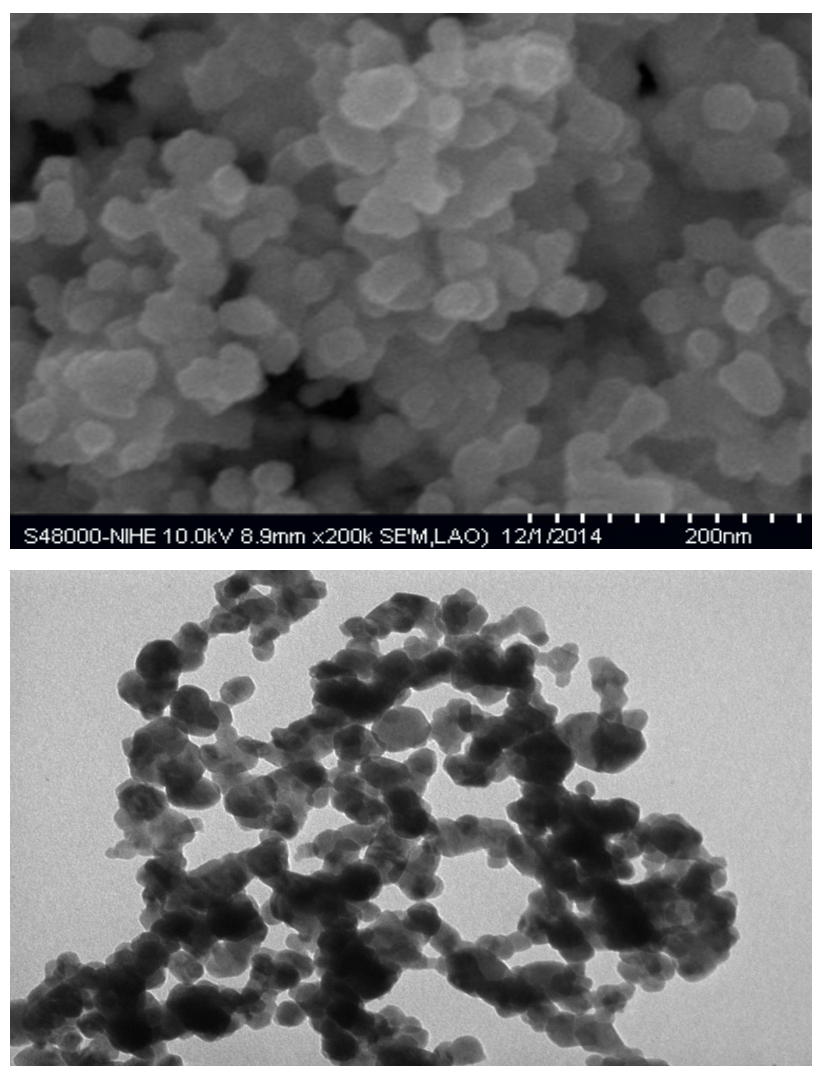

Figure 2. SEM (a) and TEM (b) image of nanocrystalline $\mathrm{Cu}$ prepared by the chemical reduction method.

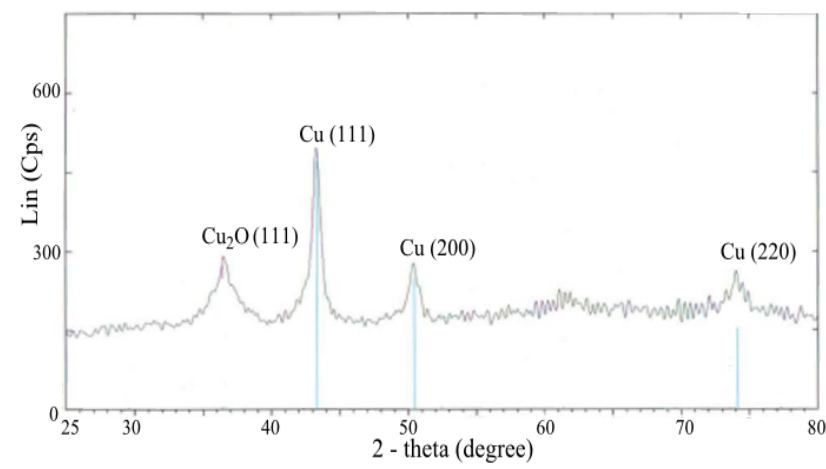

Figure 3. XRD patterns of nanocrystalline $\mathrm{Cu}$ prepared by the chemical reduction method

\subsection{Phytoplankton community under CuNPs exposure}

The microscope examination of the phytoplankton samples collected from the Tien Lake showed the dominance of cyanobacteria during the study period. In the Tien Lake, cyanobacteria contributed considerably to the total densities with the number of cells ranging from $487.222 \pm$ 14.928 to $467.037 \pm 28.422$ cells $\mathrm{mL}^{-1}$ (Table 1 ). The main taxa of the cyanobacteria were Microcystis genus and the blooms of Microcystis in the Tien Lake composed of three species: M. aeruginosa, M. wesenbergii and $M$. ichthyoblabe. Other cyanobacteria found in small amounts were Oscillatoria, Aphanocapsa, Anabaena. Besides Microcystis, the phytoplankton assemblage included a few species belonging to several classes of Cyanobacteria, Chlorophyta and Bacillariophyta such as Scenedesmus sp1, Senedesmus sp2, Coelactrum sp, N. gracillis, Nitzschia $s p$ respectively." 
Aggregation of nanoparticles has been shown to have risk implications to human and aquatic organisms (Jing Ji et al, 2011; Hund-Rinke et al, 2006; Lovern et al, 2006; Zhu et al, 2006). Potential effects of metal nanoparticles on aquatic ecosystems and phytoplankton community had been investigated. At present, the knowledge on the ecotoxicological effects of NPs is still limited. It is hard to predict from the results of single-species tests under controlled laboratory conditions, therefore realistic experiments have received considerable attention. A full assessment of the effective of NPs exposure for aquatic ecosystems will need to investigate including the biological, physical and chemical variables of natural environments. However, the effect of different materials is different. The toxicity of metals (e.g., $\mathrm{TiO}_{2}, \mathrm{Cu}, \mathrm{Ni}, \mathrm{Ag}$...etc) in aquatic environments depends on water quality, particle size or concentration of nutrients (Blahoslav et al, 2012).

In our study, the toxicity of the copper nanoparticles against the phytoplankton (dominated by Microcystis genus) was monitored in the Tien lake water sample. $\mathrm{pH}$ and Turbidity in control samples increased, whereas those values in samples treated with CuNPs decreased. However, the one-way ANOVA results showed that there were no significant between $\mathrm{pH}$ and Turbidity in both kinds of samples (Control and treated with CuNPs) $(p>0.05)$. CuNPs exposure caused significant effects on growth of phytoplankton biomass. Figure 5 and Table 1 illustrate that the variables including Phytoplankton density, Chlorophyll a and concentrations of $\mathrm{NH}_{4}{ }^{+}, \mathrm{PO}_{4}{ }^{3-}$ have been strongly decreased in both kinds of samples (Control and treated with CuNPs) and significantly different between the first day and the last day of experimental period. The concentration of Chlorophyll a in the aquarium tanks treated with CuNPs was significantly lower than that in control aquarium tanks. It can be inferred that as the $\mathrm{pH}$ decreased, acidic was also higher, the content of dissolved copper metal was higher and the agglomeration of nanoparticles increased inside the algal cell lead to cell death.
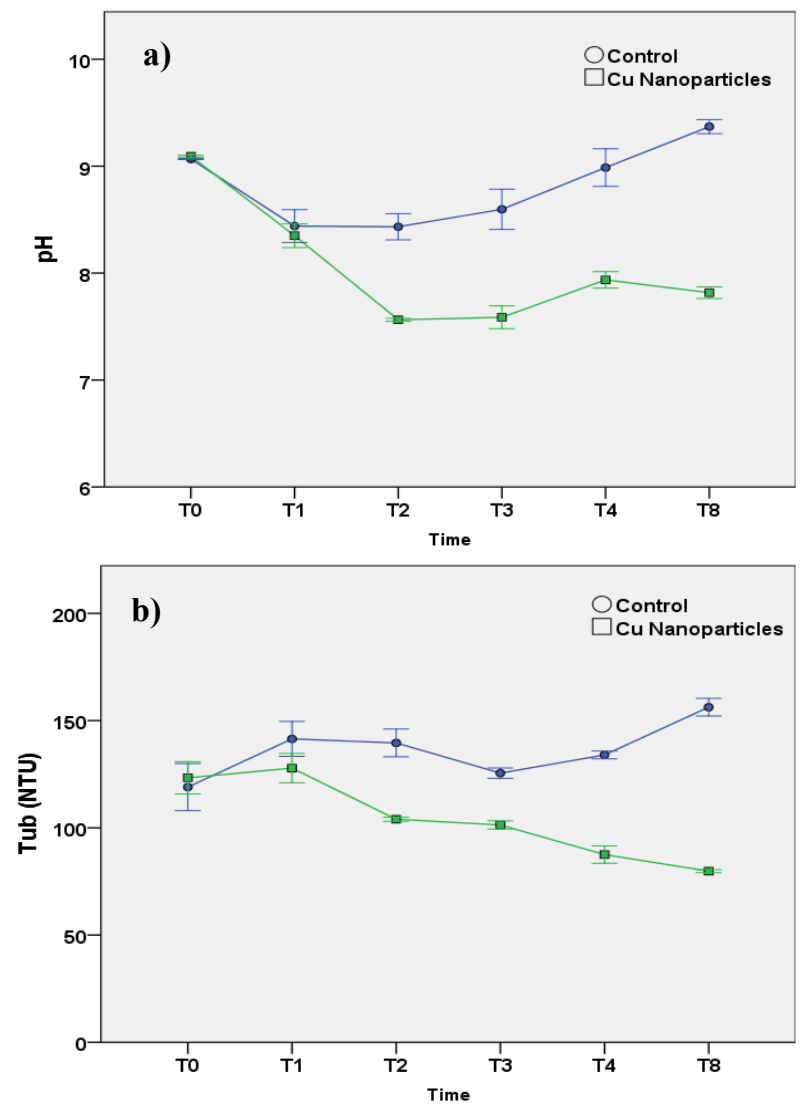

Figure 4. The variability of physical analysis values: pH (a) and Turbidity (b) of the 2 sets of aquarium (Control and treated with CuNPs) monitored during 8 days of experiment. Values are reported as mean of 3 replicates $\pm \mathrm{SD}(\mathrm{n}=3)$

\section{Table 1. The phytoplankton density in aquarium tanks (control and CuNPs samples) at D0 and D8}

\section{Phytoplankton density (cell/mL)}

\begin{tabular}{ll}
\hline Control & Phytoplankton \\
& Microcystis \\
Treatment with CuNPs $1 \mu \mathrm{g} / \mathrm{L}$ & Phytoplankton \\
& Microcystis
\end{tabular}

Recently, the few studies have investigated the influence of eutrophication on NPs toxicity, it found that the levels of nutrient availability increased may lessen the negative effects of NPs exposure on aquatic bacterial (Xiu et al, 2011), algal (Das et al, 2014) and zooplankton (McTeer et al, 2014). Some studies explained that the copper metals attached and absorbed to the algal cell wall, fixed inside the cell, activated to be more toxic to cells lead to cell death and sank to the bottom of the aquariums (Chen et al, 2012; Mafalda et al, 2015; Wang et al, 2011). Moreover, the other research indicated that, the nanomaterials have small size and different shape can increase the osmotic of the cell membrane leading to effect on cell osmotic and inhibition of cell growth (Park et al, 2010). Indeed, Fred Rispoli (2010) also found that under acidic conditions and higher temperature, the mean size of nanoparticles aggregate is
D0

$\begin{array}{ll}623888 \pm 28333 & 690000 \pm 11111 \\ 487222 \pm 14928 & 427777 \pm 31991 \\ 647037 \pm 32967 & 381111 \pm 18492 \\ 467037 \pm 28422 & 202592 \pm 14156\end{array}$

lower. This increases the surface area available for the solubilization of copper ions into the medium and thus increases the observed toxicity. Serra (2010) demonstrated that both of two kinds of $\mathrm{P}$ in the culture played an important role modulating the toxicological of $\mathrm{Cu}$. However, Choi (2009) indicated that the eutrophication pollutant (especially the abundance of $\mathrm{PO}_{4}{ }^{3-}$ ) had less effect on NPs toxicity to bacteria and Chlamydomonas reinhardtii (McTeer et al, 2014). Some researches support the hypothesis that metal toxicity is reduced when the concentrations of nutrients increase (Harding et al, 1977; Chen et al, 1994). In the contrast, several studies indicated that metals caused nutrient limitation and then reduced algal growth (Paulsson et al, 2002; Meylan et al, 2004). The potential of NPs as a toxicity factor for phytoplankton community needs to be investigated further, particularly in natural environments. 

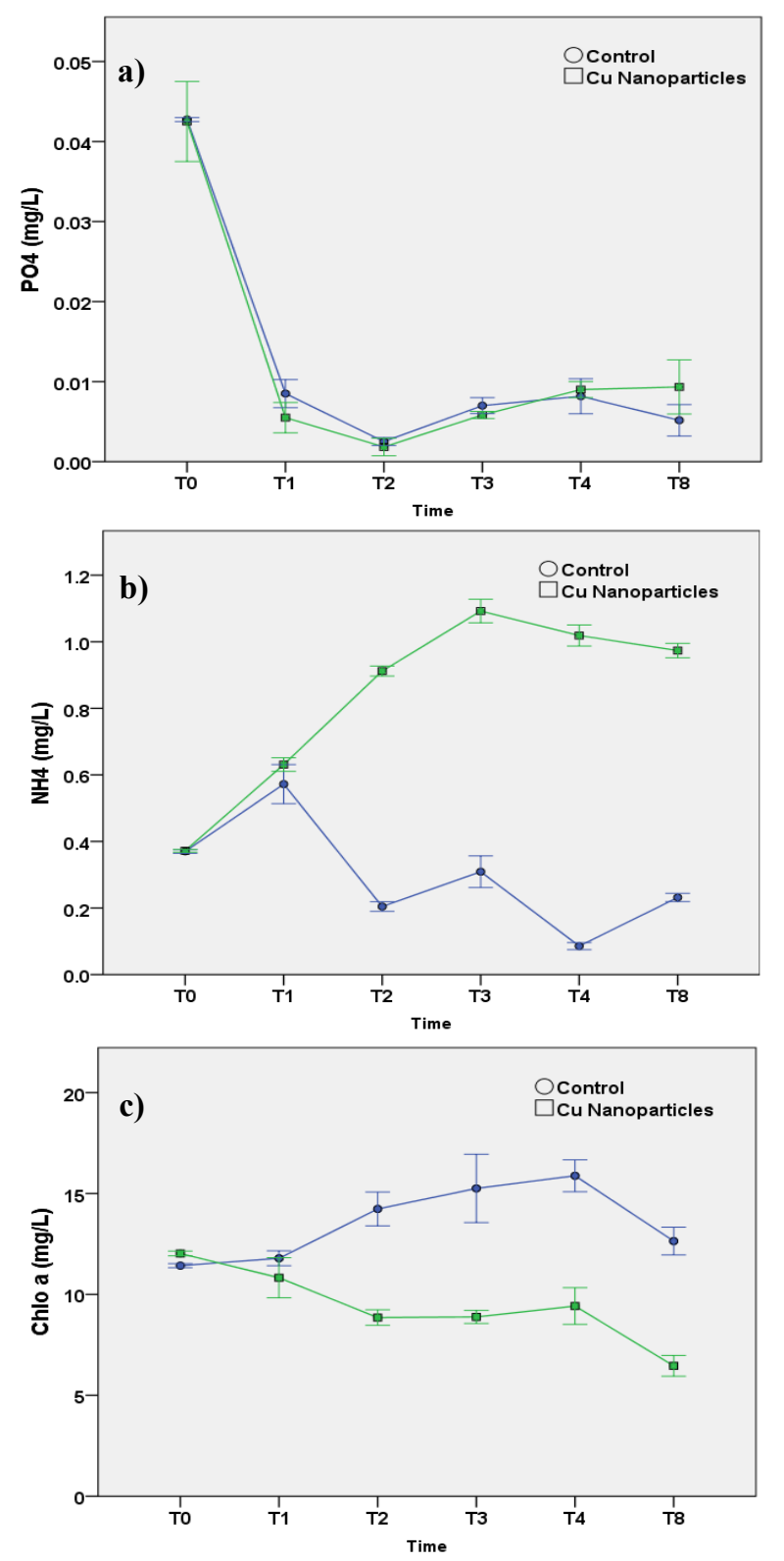

Figure 5. The variability of average concentration of biochemical parameters: Phosphate (a), Ammonium (b) and Chlorophyll a (c) of the 2 sets of aquarium (Control and treated with CuNPs) monitored during 8 days of experiment. Values are reported as mean of 3 replicates $\pm S D(n=3)$.

\section{Conclusion}

The copper nanoparticles were synthesized by reduction method. The characteristic of nanomaterial was confirmed by using UV-visible spectrophotometer, XRD, SEM and TEM. The CuNPs obtained from material synthesized experiments were spherical form and uniform size about 20$40 \mathrm{~nm}$. The experimental results at laboratory scale showed that the toxicity of copper nanoparticles inhibited growth and development of phytoplankton and Microcystis genus in aquarium tanks containing Tien Lake water.

\section{Acknowledgements}

This study was realized in the framework of the VAST0701/15-16 projects. The authors are grateful for the financial supports from Vietnam Academy of Science and Technology (VAST).

\section{References}

[1] Aruoja,V., Dubourguier, H.C., Kasemets, K. (2008) Toxicity of nanoparticles of $\mathrm{CuO}, \mathrm{ZnO}$ and $\mathrm{TiO} 2$ to microalgae Pseudokirchneriella subcapitata. Sci. Total Environ. 407: 1461-1468.

[2] Mahltig, B., Soltmann, U., Haase, H. (2013) Modification of algae with zinc, copper and silver ions for usage as natural composite for antibacterial applications. Materials Science and Engineering C. 33: 979983.

[3] Marsalek, B., Jancula, D. (2012) Multimodal action and selective toxicity of zerovalent iron nanoparticles against cyanobacteria Environmental Science and technology. 46: $2316-2323$.

[4] Chen, C.Y. (1994) Theoretical evaluation of the inhibitory effects of mercury on algal growth at various orthophosphate levels. Water Res. 28: 931-937

[5] Chen, L., Zhoub, L., Liu, Y., Deng, S., Wu, H., Wang, G. (2012) Toxicological effects of nanometer titanium dioxide (nano- $\mathrm{TiO} 2$ ) on Chlamydomonas reinhardtii. Ecotoxicol Environ Safe. 84:155-62.

[6] Choi, OK., Hu, ZQ. (2009) Nitrification inhibition by silver nanoparticles. Water Sci Technol. 59: 16991702.

[7] Colman, B.P., Espinasse, B., Richardson, C.J., Matson, C.W., Lowry, G.V., Hunt, D.E. (2014) Emerging contaminant or an old toxin in disguise silver nanoparticle impacts on ecosystems. Environ Sci Technol. 48:5229-5236.

[8] Dang, T., Ho, H. (2007) Fundamentals of Hydrobiology. Hanoi: PST.

[9] Das, P., Xenopoulos, M.A., Williams, C.J., Hoque, M.E., Metcalfe, C.D. (2012) Effects of silver nanoparticles on bacterial activity in natural waters. Environ Toxicol Chem. 31: 122-130.

[10] Drabkova, M., Marsalek, B., Admiraal, W. (2007) Photodynamic therapy against cyanobacteria. Environ Toxicol. 22:112-115.

[11] Zowalaty, E.1., Ibrahim, M., Salama, N., Shameli, M., Usman, M. K., Zainuddin, N. (2013) Synthesis, characterization, and antimicrobial properties of copper nanoparticles. International Journal of Nanomedicine. 8: $4467-4479$.

[12] Rispoli, F., Angelov, A., Badia, D., Kumar, A., Seal, S., Shah, V. (2010) Understanding the toxicity of aggregated zero valent copper nanoparticles against Escherichia coli, Journal of Hazardous Materials. 180: 212-216

[13] Harding, J.P.C., Whitton, B.A. (1977) Environmental factors reducing the toxicity of zinc to Stigeoclonium tenue. Br Phycol J. 12:17-21

[14] Heinlaan, M., Kahru, A., Kasemets, K., Arbeille, B., Prensier, G. (2011) Changes in the Daphnia magna 
midgut upon ingestion of copper oxide nanoparticles: a transmission electron microscopy study. Water Res. 45: $179-190$

[15] Hund-Rinke, K., Simon, M. (2006) Ecotoxic effect of photocatalytic active nanoparticles $\mathrm{TiO} 2$ on algae and daphnids. Environ. Sci. Pollut. Res. 13: 225-232

[16] Ingle, A., Duran, N., Rai, M. (2013) Bioactivity, mechanism of action and cytotoxicity of copperbased nanoparticles: A review. Appl Microbiol Biotechnol. 98(3): 1001-1009.

[17] Jayatissa, L.P., Silva, E.I.L., McElhiney, J., Lawton, L.A. (2006) Occurrence of toxigenic cyanobacterial blooms in freshwaters of Sri Lanka. Systematic and Applied Microbiology. 29: 156 - 164.

[18] Jing, J., Zhifeng, L., Daohui, L. (2011) Toxicity of nanoparticles to the green algae Chlorella sp., Chemical Engineering Joural. 170(9): 525 - 530.

[19] Kasemets, K., Ivask, A., Dubourguier, H.C., Kahru, A. (2009) Toxicity of nanoparticles of $\mathrm{ZnO}, \mathrm{CuO}$ and $\mathrm{TiO} 2$ to yeast Saccharomyces cerevisiae. Toxicol. in Vitro. 23:1116-1122

[20] Klug, H.P., Alexander, L. E. (1997) X-ray diffraction procedures for polycrystalline and amorphous materials ( 2 nd ed., John Wiley \& Sons, New York).

[21] Lovern, S.B., Klaper, R. (2006) Daphnia magna mortality when exposed to titanium dioxide and fullerene (C-60) nanoparticles. Environ. Toxicol. Chem. 25: 1132-1137

[22] Baptista, M.S., Miller, R.J., Halewood, E.R., Hanna, S.K., Almeida, C.M.R., Vasconcelos, V.M., Keller, A.A., Lenihan H.S. (2015) Impacts of silver nanoparticles on a natural estuarine plankton community; Environ. Sci. Technol. 49(21):12968-12974.

[23] McTeer, J., Dean, A.P., White, K.N., Pittman, J.K. (2014) Bioaccumulation of silver nanoparticles into Daphnia magna from a freshwater algal diet and the impact of phosphate availability. Nanotoxicology. 8: 305-316

[24] Meylan, S., Odzak, N., Behra, R., Sigg, L. (2004)
Speciation of copper and zinc in natural freshwater: comparison of voltammetric measurements, diffusive gradients in thin films (DGT) and chemical equilibrium models. Anal Chim Acta. 510: 91-100

[25] Park, M.H., Han, M.S., Ahn, C.Y., Kim, H.S., Yoon, B.D., Oh, H.M. (2006) Growth inhibition of bloomforming cyanobacterium Microcystis aeruginosa by rice straw extract. LettApplMicrobiol. 43: 307-312.

[26] Park, M.H., Kim, K.H., Lee, H.H., Kim, J.S., Hwang, S.J. (2010) Selective inhibitory potential of silver nanoparticles on the harmful cyanobacterium Microcystis aeruginosa. Biotechnol Lett. 32: 423-428.

[27] Paulsson, M., Mansson, V., Blanck, H . (2002) Effects of zinc on the phosphorus availability to periphyton communities from the river Göta Älv. Aquat Toxicol. 56: 103-113

[28] Ngo, Q.B., Dao, T.H., Nguyen, H.C., Tran, X.T., Nguyen, V.T., Khuu, T.D., Huynh, T.H. (2014) Effects of nanocrystalline powders $(\mathrm{Fe}, \mathrm{Co}$ and $\mathrm{Cu})$ on the germination, growth, crop yield and product quality of soybean (Vietnamese species DT-51). Adv. Nat. Sci.: Nanosci. Nanotechnol. 5: 015016 (7pp).

[29] Serra, A., Guasch, H., Admiraal, W., Van, G.H.G., Van, B.A.M. (2010) Influence of phosphorus on copper sensitivity of fluvial periphyton: the role of chemical, physiological and community-related factors. Ecotoxicology. 19: 770-780.

[30] Wang, Z., Li, J., Zhao, J., Xing, B. (2011) Toxicity and Internalization of $\mathrm{CuO}$ Nanoparticles to Prokaryotic Alga Microcystis aeruginosa as Affected by Dissolved Organic Matter. Environ. Sci. Technol. 45: 6032-6040.

[31] Xiu, Z.M., Ma, J., Alvarez, P.J.J. (2011) Differential effect of common ligands and molecular oxygen on antimicrobial activity of silver nanoparticles versus silver ions. Environ Sci Technol. 45: 9003-9008

[32] Zhu, S., Obe rdör ster, E., Haasch, M.L. (2006) Toxicity of an engineered nanoparticle (fullerene, C(60)) in two aquatic species, Daphnia and fat head minnow. Mar. Environ. Res. 62: S5-S9. 